\title{
Nitrous oxide emissions from multiple combined applications of fertiliser and cattle slurry to grassland
}

\author{
R. L. M. Schils • J. W. van Groenigen • \\ G. L. Velthof • P. J. Kuikman
}

Received: 21 December 2007 / Accepted: 22 April 2008 / Published online: 24 May 2008

(C) The Author(s) 2008

\begin{abstract}
Fertiliser and manure application are important sources of nitrous oxide $\left(\mathrm{N}_{2} \mathrm{O}\right)$ emissions from agricultural soils. The current default IPCC emission factor of $1.0 \%$ is independent of the type of fertiliser and manure, and application time, method and rate. However, in the IPCC Tiered system it is possible to use more specific emission factors that better reflect the actual fertiliser and manure management in a given country or region. The first and primary aim of this study was to determine whether the combination of cattle slurry injection with fertiliser application, which is common practice in intensively managed grasslands in the Netherlands and neighbouring countries, warrants an adjusted emission factor. A second aim was to evaluate whether alternative emission factors, based on $\mathrm{N}$ uptake and $\mathrm{N}$ surplus, respectively, give more insight in the $\mathrm{N}_{2} \mathrm{O}$ emission rates of various fertilisation strategies. In a 2-year field experiment on sandy soil in the Netherlands we measured the annual $\mathrm{N}_{2} \mathrm{O}$ emission from grasslands
\end{abstract}

Responsible Editor: Ute Skiba.

R. L. M. Schils $(\bowtie) \cdot J$. W. van Groenigen •

G. L. Velthof $\cdot$ P. J. Kuikman

Alterra, Wageningen University and Research Centre,

P.O. Box 47, 6700 AA Wageningen, The Netherlands

e-mail: rene.schils@wur.nl

J. W. van Groenigen

Department of Soil Quality,

Wageningen University and Research Centre,

P.O. Box 47, 6700 AA Wageningen, The Netherlands receiving repeated simultaneous applications of fertiliser and cattle slurry. The $\mathrm{N}_{2} \mathrm{O}$ fluxes and $\mathrm{N}$ uptake by grass were measured from plots receiving calcium ammonium nitrate (CAN) at four application rates, either with or without additional application of liquid cattle slurry, applied through shallow soil injection. The average emission factor for fertiliser-only treatments was $0.15 \%$. The annual $\mathrm{N}_{2} \mathrm{O}$ emissions were similar for treatments receiving only fertiliser or only cattle slurry. In the first experimental year, application of cattle slurry increased the emission factor for fertiliser to $0.35 \%$, but the second year showed no effect of cattle slurry on the emission from fertiliser. With regard to the first objective, we conclude that these results do not conclusively justify an adjusted emission factor for combined application of fertiliser and cattle slurry. To minimise risks however, it is sensible to avoid simultaneous application of fertiliser and cattle slurry. The $\mathrm{N}_{2} \mathrm{O}$ emission factor expressed as percentage of $\mathrm{kg} \mathrm{N}$ uptake by grass was consistently higher after combined application of fertiliser and cattle slurry $(0.29 \%)$, compared to fertiliser-only $(0.17 \%)$. With regard to the second objective we conclude that an emission factor based on $\mathrm{N}$ uptake expresses the relatively inefficient $\mathrm{N}$ supply of cattle slurry to crop growth better than the traditional emission factor based on $\mathrm{N}$ application.

Keywords Cattle slurry - Emission factor · Fertiliser . Grassland $\cdot$ Manure $\cdot$ Nitrous oxide 


\section{Introduction}

Soil applied fertiliser and animal wastes are the two most important sources of direct nitrous oxide $\left(\mathrm{N}_{2} \mathrm{O}\right)$ emissions from agricultural soils (Mosier et al. 1998). In the European Union (EU-15), 40\% of the direct soil emission is attributed to fertiliser application, and another $21 \%$ to manure application (EEA 2006). In the year 2000, grasslands in the EU-15 received approximately $24 \%$ of the total amount of applied fertiliser $\mathrm{N}$, and $32 \%$ of the applied manure $\mathrm{N}$ (Velthof et al. 2007). The default IPCC emission factor, i.e. the percentage of applied $\mathrm{N}$ emitted as $\mathrm{N}_{2} \mathrm{O}$, is $1.00 \%$, irrespective of the type of fertiliser or manure (IPCC 2006). Also application time, application method and application level are not considered. The default emission factor is based on an average of published measurements on a wide range of soil types, crops, fertiliser types, $\mathrm{N}$ sources, $\mathrm{N}$ levels and application times and methods (Bouwman 1996; Bouwman et al. 2002; Stehfest and Bouwman 2006). Individual countries can use a different emission factor that corresponds to country-specific soil types or farm management. The data used to derive the IPCC default emission factor originate predominantly from fertiliser experiments. For grassland, the dataset contains relatively few experiments with organic $\mathrm{N}$ sources or combinations of fertiliser and organic N. This is in contrast with the farming practice of intensively managed grasslands in Europe, where both fertiliser and cattle slurry are usually applied shortly after one another. In those cases, interactions between those different $\mathrm{N}$ sources should be considered. Therefore, following the Tiered system for country-specific emission factors, it is useful to measure $\mathrm{N}_{2} \mathrm{O}$ emissions of fertiliser $\mathrm{N}$ in combination with applied cattle slurry. In recent years, some experiments were carried out with combined application of fertiliser and cattle slurry to grassland (Clayton et al. 1997; Dittert et al. 2005; Stevens and Laughlin 2001, 2002). All experiments reported higher $\mathrm{N}_{2} \mathrm{O}$ emissions when fertiliser and cattle slurry where applied simultaneously than when they were applied separately or with a larger interval in-between. These higher $\mathrm{N}_{2} \mathrm{O}$ losses were attributed to enhanced denitrification through the simultaneous availability of fertiliser derived nitrate $\left(\mathrm{NO}_{3}\right)$ and cattle slurry derived easy degradable carbon (C). However, in these experiments cattle slurry was surface-applied.
Efforts in recent years to reduce ammonia losses have led to an increased use of animal slurry injection techniques, especially in the Netherlands. Studies that compared application techniques of cattle slurry have either shown no effect of application technique (e.g. Velthof et al. 1996) or a higher $\mathrm{N}_{2} \mathrm{O}$ emission following cattle slurry injection (e.g. Rodhe et al. 2006). However, these experiments had no treatments with combined fertiliser and cattle slurry application and therefore did not consider possible interactions. To our knowledge, there are no published $\mathrm{N}_{2} \mathrm{O}$ emission measurements following a combined application of fertiliser and injected cattle slurry on grassland.

Intensively managed grasslands in North-West Europe are usually fertilised four to seven times a year, combined with two to four cattle slurry applications (Unwin and Vellinga 1994; Schröder et al. 2007). Therefore, the current practice might require a specific emission factor, other than the IPCC default. The primary objective of this paper was to assess the annual $\mathrm{N}_{2} \mathrm{O}$ emission from intensively managed grasslands fertilised according to common agricultural practice in the Netherlands, i.e. with repeated simultaneous applications of fertiliser and injected cattle slurry. More specific, we aim to determine the effect of cattle slurry application on the $\mathrm{N}_{2} \mathrm{O}$ emission from fertiliser.

The IPCC emission factors imply a linear relationship between $\mathrm{N}$ input and $\mathrm{N}_{2} \mathrm{O}$ emissions. The principal advantage of this approach is that the activity data, at least for fertiliser use, are relatively easy to collect and use in national inventory systems. A drawback is that the fixed emission factors only stimulate mitigation through reduced inputs and are not an incentive to improve the $\mathrm{N}$ use efficiency by crops. Experiments with different application rates have shown increased emission factors with increasing application rates (Ryden 1983), but others have found contrasting results (Velthof et al. 1996), that were attributed to the differences between sites in soil inorganic $\mathrm{N}$ accumulation. The use of process-orientated simulation models, e.g. DNDC (Li et al. 1992), may to some extent clarify these uncertainties, but the scope for general application of such models is limited. Emission factors based on either $\mathrm{N}$ uptake by crops or $\mathrm{N}$ surplus, i.e. the difference between $\mathrm{N}$ input through fertilisers and manure and the $\mathrm{N}$ output through crop uptake, may provide attractive alternatives. An 
emission factor based on crop $\mathrm{N}$ uptake might be a better expression of the effectiveness of a cropping system in producing biomass while minimizing greenhouse gas emissions. An emission factor based on the $\mathrm{N}$ surplus may be a more realistic candidate for a linear emission factor, as it corrects for $\mathrm{N}$ uptake efficiency. Therefore the second objective of this paper was to compare the emission factors for $\mathrm{N}$ input with emission factors linked to $\mathrm{N}$ uptake and $\mathrm{N}$ surplus.

To address these objectives, we carried out a 2-year experiment in which $\mathrm{N}$ uptake and $\mathrm{N}_{2} \mathrm{O}$ emission was measured from multiple applications of fertiliser and cattle slurry, separately or combined, and at different fertiliser application rates. The experiment was carried out on a sandy soil as the farms on those soils are among the most intensive farms in Europe, with high applications of cattle slurry and fertiliser. Application of cattle slurry through injection techniques are mostly applied on these lighter soil types.

\section{Materials and methods}

\section{Location}

The experiment was carried out at the Droevendaal experimental farm in Wageningen, the Netherlands $\left(51^{\circ} 59^{\prime} \mathrm{N}, 5^{\circ} 39^{\prime} \mathrm{E}\right)$. The soil is an umbric gleysoil (FAO 1998) with $3.5 \%$ organic matter and a $\mathrm{pH}_{\mathrm{KCl}}$ of 5.5 in the top soil $(0-5 \mathrm{~cm})$. The experimental field was located on a larger field that was ploughed and reseeded in the autumn of 1999 with a $100 \%$ perennial ryegrass (Lolium perenne L.) seed mixture. In the previous years, the area was used for alternate cutting and grazing with an average fertiliser application of 200 to $300 \mathrm{~kg} \mathrm{~N}^{-1}$ year $^{-1}$ and additional cattle slurry application of 20 to $40 \mathrm{t} \mathrm{ha}^{-1}$ year $^{-1}$.

\section{Experimental setup}

The core of the experiment consisted of a comparison of treatments receiving either fertiliser alone with treatments receiving fertiliser and cattle slurry. The fertiliser used was calcium ammonium nitrate (CAN, $13.5 \% \mathrm{NH}_{3}-\mathrm{N}$ and $13.5 \% \mathrm{NO}_{3}-\mathrm{N}$ ), which is the most commonly used fertiliser type in the Netherlands. The cattle slurry was liquid slurry with an average total $\mathrm{N}$ content of 4.17 and $4.93 \mathrm{~g} \mathrm{~kg}^{-1}$ in the first and second year, respectively. The proportion of $\mathrm{NH}_{4}-\mathrm{N}$ was $47 \%$ in the first year and $50 \%$ in the second year. Fertiliser was broadcast by hand. The cattle slurry was applied, according to common practice on mineral soils in the Netherlands, with a shallow injection technique, applying the cattle slurry in open equidistant slits $(20 \mathrm{~cm})$, approximately $2 \mathrm{~cm}$ wide and with a depth of $10 \mathrm{~cm}$.

Both the fertiliser-only and fertiliser-slurry treatments were carried out at four fertiliser application levels (Table 1). The resulting eight treatments were laid out in a randomised block design with three replicates. Plots were $10 \mathrm{~m}$ by $2.8 \mathrm{~m}$. The $\mathrm{N}$ application levels on the fertiliser-only treatments CAN_0, CAN_50, CAN_75 and CAN_100 were 0, 160, 240 and $320 \mathrm{~kg} \mathrm{ha}^{-\overline{1}}$ year $^{-1}$, respectively. The distribution of the annual fertiliser application over the five cuts was $35,20,15,15$ and $15 \%$, respectively. The treatments with combined fertiliser and cattle slurry application, received $90 \mathrm{t} \mathrm{ha}^{-1}$ year $^{-1}$ of cattle slurry, supplemented with either $0,120,180$ or $240 \mathrm{~kg} \mathrm{~N}^{-1}$ year $^{-1}$ from fertiliser for treatments CS_0, CS_50, CS_75 and CS_100, respectively. Cattle slurry was applied at a rate of $30 \mathrm{t} \mathrm{ha}^{-1}$ for the first and second cut, and $15 \mathrm{tha}^{-1}$ for the third and fourth cut. The distribution of the annual fertiliser application was adapted to match the fertilising value of the applied cattle slurry, and was $30,20,15,15$ and $20 \%$ for the five consecutive cuts, respectively. On the fertiliser-slurry treatments, fertiliser and cattle slurry were applied on the same day.

The experiment was carried out in the year 2001 and 2002 , both years on the same plots.

Grass and soil analysis

All plots were harvested five times, between May and October of each year, with a Haldrup plot harvester at a cutting height of $5 \mathrm{~cm}$. Fresh grass yields were determined and samples were taken for analysis on dry matter (DM) and total N. The DM content was determined after $48 \mathrm{~h}$ drying at $70^{\circ} \mathrm{C}$. Dried samples were milled and total $\mathrm{N}$ content was determined spectrophotometrically after destruction with $\mathrm{H}_{2} \mathrm{SO}_{4}$ using standard methodology in a mixture with salicylic acid and $\mathrm{Se}$, to which $\mathrm{H}_{2} \mathrm{O}_{2}$ was added.

The DM yield and $\mathrm{N}$ uptake was calculated from the fresh yields, DM contents and $\mathrm{N}$ contents. The apparent $\mathrm{N}$ recovery (ANR) of fertiliser and cattle slurry in harvested grass was calculated from the $\mathrm{N}$ 
Table 1 Annual nitrogen application rates from fertiliser and cattle slurry, dry matter and nitrogen uptakes, nitrous oxide emissions and emission factors

\begin{tabular}{|c|c|c|c|c|c|c|c|c|c|}
\hline Treatment & $\begin{array}{l}\text { Fertiliser } \\
\left(\mathrm{kg} \mathrm{N} \mathrm{ha}^{-1}\right)\end{array}$ & $\begin{array}{l}\text { Cattle slurry } \\
\left(\mathrm{kg} \mathrm{N} \mathrm{ha}^{-1}\right)\end{array}$ & $\begin{array}{l}\text { DM yield } \\
\left(\mathrm{kg} \mathrm{ha}^{-1}\right)\end{array}$ & $\begin{array}{l}\text { N uptake } \\
\left(\mathrm{kg} \mathrm{ha}^{-1}\right)\end{array}$ & $\begin{array}{l}\mathrm{N}_{2} \mathrm{O}^{\mathrm{a}} \\
\left(\mathrm{kg} \mathrm{N} \mathrm{ha}^{-1}\right)\end{array}$ & $\begin{array}{l}\text { EF_applied }{ }^{b} \\
(\%)\end{array}$ & $\begin{array}{l}\text { EF_applied }{ }^{\mathrm{c}} \\
(\%)\end{array}$ & $\begin{array}{l}\text { EF_uptake } \\
(\%)\end{array}$ & $\begin{array}{l}\text { EF_surplus } \\
(\%)\end{array}$ \\
\hline \multicolumn{10}{|l|}{2001} \\
\hline CAN_0 & 0 & 0 & 3,195 & 65 & $0.04(0.07)$ & & & 0.07 & -0.07 \\
\hline CAN_50 & 120 & 0 & 7,048 & 175 & $0.17(0.18)$ & 0.11 & & 0.10 & -0.31 \\
\hline CAN_75 & 240 & 0 & 9,356 & 263 & $0.60(0.67)$ & 0.23 & & 0.23 & -2.59 \\
\hline CAN_100 & 330 & 0 & 10,240 & 314 & $0.60(0.56)$ & 0.17 & & 0.19 & 3.86 \\
\hline CS_0 & 0 & 375 & 8,116 & 196 & $0.46(0.52)$ & 0.11 & & 0.24 & 0.26 \\
\hline CS_50 & 120 & 375 & 11,123 & 295 & $0.87(0.93)$ & 0.17 & 0.34 & 0.30 & 0.43 \\
\hline CS_75 & 180 & 375 & 11,415 & 325 & $1.02(1.04)$ & 0.18 & 0.31 & 0.31 & 0.44 \\
\hline CS_100 & 240 & 375 & 12,250 & 367 & $1.41(1.45)$ & 0.22 & 0.40 & 0.38 & 0.57 \\
\hline \multicolumn{10}{|c|}{ Sign./LSD $(P<0.05)^{\mathrm{d}}$} \\
\hline $\mathrm{N}$ source & & & $* * *(311)$ & $* * *(10.3)$ & $* * *(0.17)$ & & & $* *(0.059)$ & NS \\
\hline $\mathrm{N}$ level & & & $* * *(439)$ & $* * *(14.5)$ & $* * *(0.24)$ & & & $*(0.083)$ & $* * *(1.9)$ \\
\hline $\mathrm{N}$ source $* \mathrm{I}$ & evel & & $* * *(621)$ & $* * *(20.5)$ & NS & & & NS & $* * *(2.7)$ \\
\hline \multicolumn{10}{|l|}{2002} \\
\hline CAN_0 & 0 & & 3,703 & 72 & 0.13 & & & 0.18 & -0.18 \\
\hline CAN_50 & 120 & & 6,613 & 150 & 0.30 & 0.14 & & 0.20 & -0.99 \\
\hline CAN_75 & 240 & & 7,308 & 208 & 0.41 & 0.12 & & 0.20 & 1.28 \\
\hline CAN_100 & 330 & & 7,962 & 275 & 0.53 & 0.12 & & 0.19 & 0.97 \\
\hline CS_0 & 0 & 444 & 10,098 & 215 & 0.66 & 0.12 & & 0.31 & 0.29 \\
\hline CS_50 & 120 & 444 & 10,956 & 291 & 0.69 & 0.10 & 0.02 & 0.24 & 0.25 \\
\hline CS_75 & 180 & 444 & 10,385 & 305 & 0.73 & 0.10 & 0.04 & 0.24 & 0.23 \\
\hline CS_100 & 240 & 444 & 10,912 & 365 & 1.14 & 0.15 & 0.20 & 0.31 & 0.36 \\
\hline \multicolumn{10}{|c|}{ Sign./LSD $(P<0.05)^{\mathrm{d}}$} \\
\hline $\mathrm{N}$ source & & & $* * *(619)$ & $* * *(23.5)$ & $* * *(0.13)$ & & & $*(0.060)$ & NS \\
\hline $\mathrm{N}$ level & & & $* * *(875)$ & $* * *(33.2)$ & $* * *(0.18)$ & & & NS & NS \\
\hline $\mathrm{N}$ source $* \mathrm{I}$ & evel & & $* *(1,237)$ & NS & NS & & & NS & NS \\
\hline
\end{tabular}

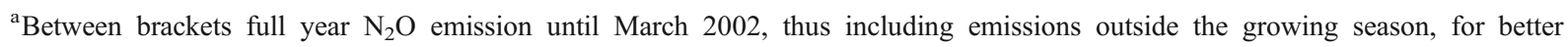
comparison with IPCC default value

${ }^{\mathrm{b}}$ Emission factor as percentage of total applied N, relative to CAN_0

${ }^{\mathrm{c}}$ Emission factor as percentage of applied fertiliser N, relative to CS_0

${ }^{\mathrm{d}}$ Signicance levels: $* * * P<0.001, * * P<0.01, * P<0.05$. LSD, Least significant difference at $P<0.05$

uptake of plots receiving only fertiliser $\left(\mathrm{NU}_{\text {fertiliser }}\right)$ or only cattle slurry $\left(\mathrm{NU}_{\text {slurry }}\right)$, the $\mathrm{N}$ uptake of the unfertilised control $\left(\mathrm{NU}_{\text {control }}\right)$, and the applied $\mathrm{N}$ $\left(\mathrm{N}_{\text {applied }}\right)$ as follows:

$$
\begin{aligned}
& \mathrm{ANR}_{\text {fertiliser/slurry }}(\%) \\
& \quad=\left(\mathrm{NU}_{\text {fertiliser/slurry }}-\mathrm{NU}_{\text {control }}\right) * 100 / \mathrm{N}_{\text {applied }}
\end{aligned}
$$

Following each harvest, but before the next fertiliser or cattle slurry application, soil samples were taken to a depth of $20 \mathrm{~cm}$. The samples were extracted with $1 \mathrm{M} \mathrm{KCl}$, after which $\mathrm{NH}_{4}{ }^{+}$and $\mathrm{NO}_{3}{ }^{-}$ concentrations were determined spectrophotometrically. The total amount of $\mathrm{NH}_{4}{ }^{+}-\mathrm{N}$ and $\mathrm{NO}_{3}{ }^{-}-\mathrm{N}$ in the layer of $0-20 \mathrm{~cm}$ was calculated, using a bulk density of $1.41 \mathrm{~g} \mathrm{~cm}^{-3}$, determined in 2002 on the same field.

Subsequently, the soil samples were dried for $24 \mathrm{~h}$ at $105^{\circ} \mathrm{C}$ to determine gravimetric soil moisture content. The gravimetric soil moisture contents were recalculated to water filled pore space (WFPS), using the bulk density of $1.41 \mathrm{~g} \mathrm{~cm}^{-3}$, and assuming densities of 1.47 and $2.65 \mathrm{~g} \mathrm{~cm}^{-3}$ for the organic and mineral soil fractions, respectively. At each flux measurement, soil temperature was measured at a depth of $10 \mathrm{~cm}$ using Pico PT-100 temperature probes.

Daily rainfall and average temperature were collected from a weather station at a distance of $1 \mathrm{~km}$ of the experimental field. 
Nitrous oxide measurements

Nitrous oxide fluxes were measured on 57 occasions between 3 April 2001 and 7 October 2002. The measuring frequency was up to three times a week after fertiliser and cattle slurry application and two to four times a month in the remainder of the growing season. An additional set of four measurements was carried out between the end of the first growing season and the start of the second growing season. To prevent effects of diurnal variation, all emission measurements were carried out between 9 and $12 \mathrm{AM}$. Although this ensures a good comparison between the daily flux measurements, the annual emission levels may have been underestimated. Earlier studies showed that diurnal $\mathrm{N}_{2} \mathrm{O}$ production varies with diurnal soil temperature, which is at its lows at sunrise (Christensen 1983; Williams et al. 1999) and peaks late afternoon.

The $\mathrm{N}_{2} \mathrm{O}$ concentrations were measured in the headspace of vented closed PVC flux chambers, with a diameter of $16 \mathrm{~cm}$ and a height of $15 \mathrm{~cm}$, using a Brüel and Kjær photo-acoustic spectroscopic infrared gas analyser (Velthof and Oenema 1995a). The flux chambers were placed onto semi-permanent rings, inserted into the soil to a depth of $2 \mathrm{~cm}$. The rings remained in the soil during each harvest cycle, and were moved to new positions after each fertiliser and cattle slurry application. The placement of the rings on the plots receiving cattle slurry received special attention in order to achieve the correct proportion between applied and non-applied surface within the flux chambers. Therefore the centre of the rings was placed at a distance of $6 \mathrm{~cm}$ from the application slit.

The $\mathrm{N}_{2} \mathrm{O}$ concentration was measured before the chambers were closed and approximately 45 to $60 \mathrm{~min}$ after closing. The analyser was attached directly to the flux chambers by two Teflon tubes. A soda lime trap was installed at the inlet of the analyser to prevent undesired accumulation of carbon dioxide $\left(\mathrm{CO}_{2}\right)$. The analyser was fitted with optical filters for selective measurement of $\mathrm{N}_{2} \mathrm{O}, \mathrm{CO}_{2}$ and water vapour. Any remaining $\mathrm{CO}_{2}$ was automatically corrected for. The accuracy of the analyser was approximately $5 \%$ in the range of 300 to $5,000 \mathrm{ppb}$.

The $\mathrm{N}_{2} \mathrm{O}$ flux was calculated as the difference between ambient concentration and the concentration in the closed chamber, assuming a linear relationship between concentration and time (Velthof and Oenema 1995a), which was occasionally checked during the experiment. The accumulated fluxes were calculated by linear interpolation between measurement days. Emission factors were calculated in three ways. In the conventional method the emission factor $\left(\mathrm{EF}_{\text {applied }}\right)$ is calculated from the $\mathrm{N}_{2} \mathrm{O}$ emission of fertilised and/or manured plots $\left(\mathrm{N}_{2} \mathrm{O}_{\text {fert }}\right)$, the $\mathrm{N}_{2} \mathrm{O}$ emission of control plots $\left(\mathrm{N}_{2} \mathrm{O}_{\text {zero }}\right)$ and the amount of total $\mathrm{N}$ applied, all expressed in $\mathrm{kg} \mathrm{N} \mathrm{ha}^{-1}$ :

$\mathrm{EF}_{\text {applied }}[\%]=\left(\mathrm{N}_{2} \mathrm{O}_{\text {fert }}-\mathrm{N}_{2} \mathrm{O}_{\text {zero }}\right) * 100 / \mathrm{N}$ applied

Alternatively, the emission $\left(\mathrm{N}_{2} \mathrm{O}\right)$ was related to the $\mathrm{N}$ uptake of grass $\left(\mathrm{EF}_{\text {uptake }}\right)$, all expressed in $\mathrm{kg} \mathrm{N} \mathrm{ha}^{-1}$, which could be calculated for each individual plot:

$\mathrm{EF}_{\text {uptake }}[\%]=\mathrm{N}_{2} \mathrm{O} * 100 / \mathrm{N}$ uptake

Finally, the emission was related to the $\mathrm{N}$ surplus $\left(\mathrm{EF}_{\text {surplus }}\right)$, defined as the difference between $\mathrm{N}$ uptake of grass and the total $\mathrm{N}$ input $\left(\mathrm{kg} \mathrm{N} \mathrm{ha}^{-1}\right)$ through fertiliser and cattle slurry:

$\mathrm{EF}_{\text {surplus }}[\%]=\mathrm{N}_{2} \mathrm{O} * 100 / \mathrm{N}$ surplus

Data analysis

A two-way analysis of variance was performed to test the effects of the main treatments, the $\mathrm{N}$ application level, and their interactions. Multiple linear regression was used to relate $\mathrm{N}_{2} \mathrm{O}$ emission with $\mathrm{N}$ application, $\mathrm{N}$ uptake or $\mathrm{N}$ surplus, and their interactions with the two $\mathrm{N}$ sources CAN and CS. The statistical analysis were carried out with GENSTAT (GENSTAT 2007).

\section{Results}

Soil

Both experimental years were relatively wet and warm, compared to the 30-year averages (19701999) of $724 \mathrm{~mm} \mathrm{year}{ }^{-1}$ and $9.5^{\circ} \mathrm{C}$. The annual precipitation was 943 and $921 \mathrm{~mm}$ in 2001 and 2002, respectively. In 2001, the most of the excess precip- 
Fig. 1 Monthly actual and 30 year average precipitation (left axis), and water filled pore space (WFPS, $0-20 \mathrm{~cm})$ at harvest (right axis)

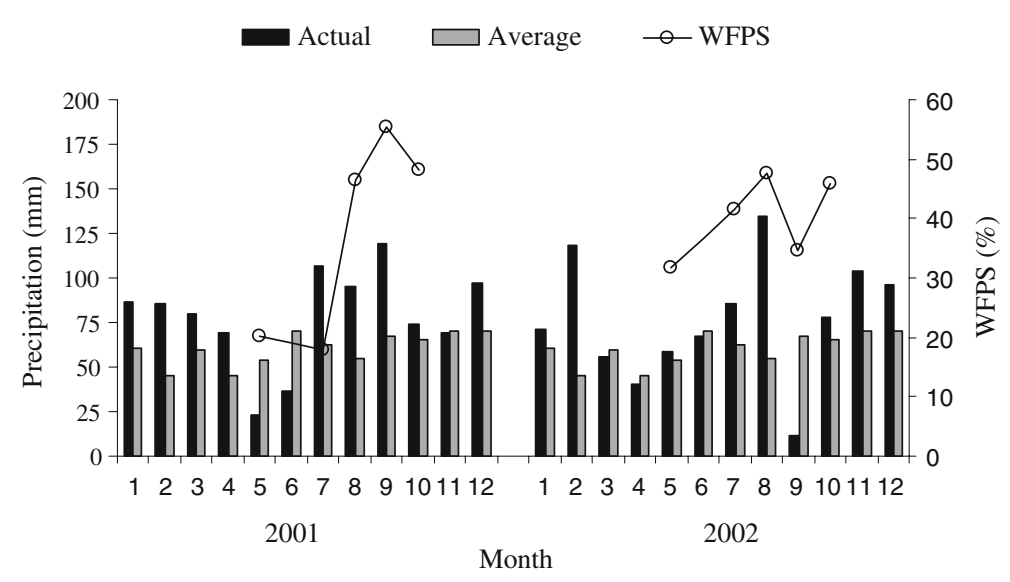

itation occurred between January and April and between August and October (Fig. 1). May and June of 2001 were relatively dry months. In 2002, February and August were extremely wet, while September was the driest month by far. The WFPS (Fig. 1) varied from $18 \%$ in May and June 2001 to around $50 \%$ at the end of the first growing season. In 2002, the WFPS values were in a smaller range in than in 2001. Due to the large measurement interval, it can not be excluded that the actual WFPS values were outside the described range.

The average annual temperatures were 10.3 and $10.7^{\circ} \mathrm{C}$ in 2001 and 2002, respectively (Fig. 2). All monthly temperatures were higher than average, but the differences were more prominent outside than during the growing season. Soil temperatures followed the pattern of air temperature and ranged from 7 to $27^{\circ} \mathrm{C}$.

The total amount of soil inorganic $\mathrm{N}$ in the top soil $(0-20 \mathrm{~cm})$ at harvest varied from less than $5 \mathrm{~kg} \mathrm{~N} \mathrm{ha}^{-1}$ to incidentally nearly $50 \mathrm{~kg} \mathrm{~N} \mathrm{ha}^{-1}$ on plots receiving the highest amounts of fertiliser and cattle slurry (Fig. 3). In the first year, significant accumulation of $\mathrm{NH}_{4}{ }^{+}-\mathrm{N}$ only occurred at the second harvest, with on average a higher accumulation on fertiliser-only plots. At the first harvest in 2002, soil $\mathrm{NH}_{4}{ }^{+}-\mathrm{N}$ was significantly $(P<0.01)$ higher on the manured plots, but without any effect of $\mathrm{N}$ level. The fourth harvest in 2002 also showed significant $\mathrm{NH}_{4}{ }^{+}-\mathrm{N}$ accumulation, with generally higher amounts on the manured plots. Differences in accumulation of $\mathrm{NO}_{3}{ }^{-}-\mathrm{N}$ occurred at nearly all harvests. Nitrate accumulation was higher on the manured plots at all harvests in the first year, and at the first, fourth and fifth harvest of the second year. Application level had a positive effect on soil $\mathrm{NO}_{3}{ }^{-}-\mathrm{N}$ at the second and third harvest in the first year, and at all harvests in the second year. The occurrence of dry periods in May and June 2001 coincided with the most noticeable accumulation in July 2001. Similarly, the accumulation in September 2002 was preceded by a dry period in the month before.

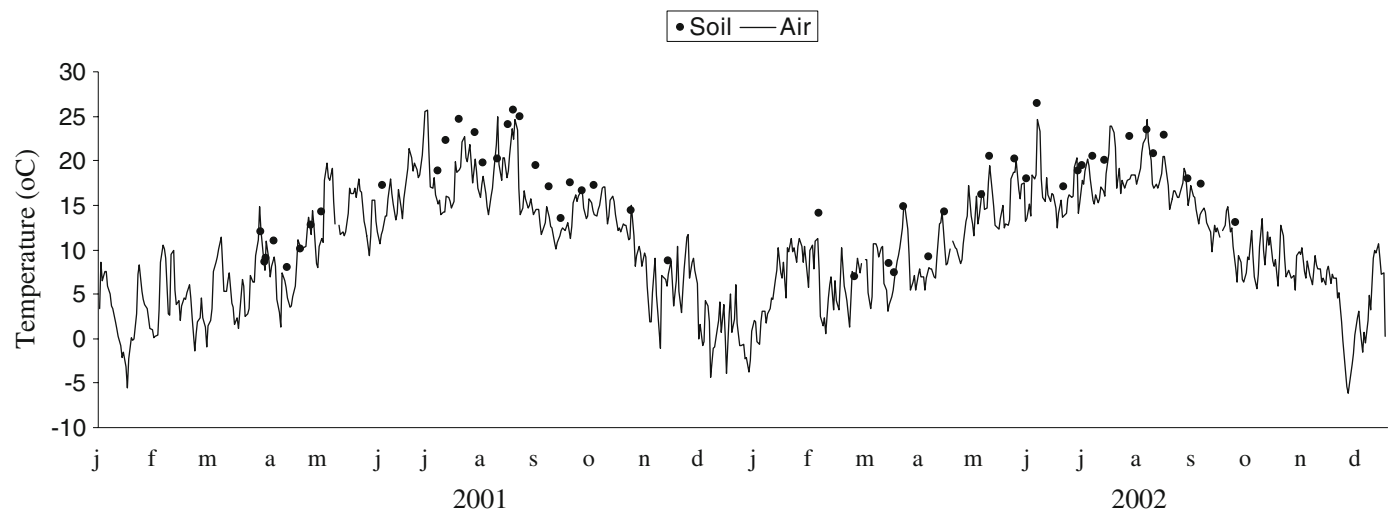

Month

Fig. 2 Mean daily air temperature at $150 \mathrm{~cm}$ and soil temperature on $\mathrm{N}_{2} \mathrm{O}$ flux measurement dates at a depth of $10 \mathrm{~cm}$ 

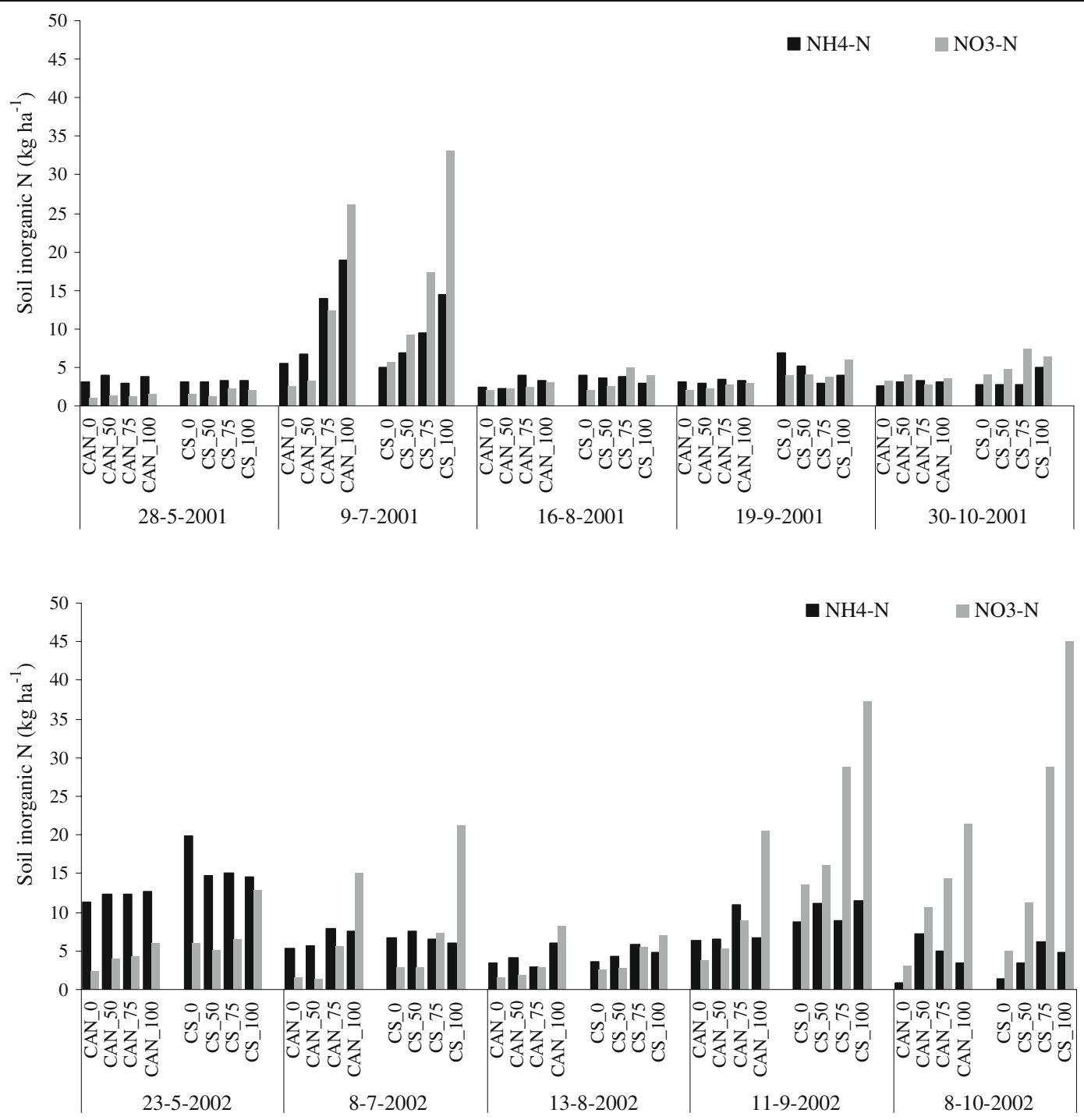

Fig. 3 Soil inorganic $\mathrm{NH}_{4}-\mathrm{N}$ and $\mathrm{NO}_{3}-\mathrm{N}$ to a depth of $20 \mathrm{~cm}$, for all treatments at all individual harvests

Grass

The DM yield of the unfertilised control plots were 3.2 and $3.7 \mathrm{t} \mathrm{ha}^{-1}$ year $^{-1}$ in the first and second year, respectively (Table 1), with corresponding annual $\mathrm{N}$ uptakes of 65 and $72 \mathrm{~kg} \mathrm{ha}^{-1}$. Application of fertiliser $\mathrm{N}$ significantly increased DM and $\mathrm{N}$ uptakes, with and without application of cattle slurry. In both years, the maximum $\mathrm{N}$ uptake was around $365 \mathrm{~kg} \mathrm{ha}^{-1}$ year ${ }^{-1}$. However, the DM production per unit $\mathrm{N}$ uptake was higher in the first than in the second year, with corresponding maximum DM yields of 12.3 and $10.9 \mathrm{t} \mathrm{DM} \mathrm{ha}^{-1}$ year $^{-1}$ for 2001 and 2002, respectively.
The ANR of fertiliser-N ranged from 69 to $82 \%$ in the first year, and from 56 to $65 \%$ in the second year. The ANR of slurry-N was 35 and $30 \%$ in year 1 and two, respectively.

Nitrous oxide emissions

The $\mathrm{N}_{2} \mathrm{O}$ fluxes varied from $-1.6 \mathrm{~g} \mathrm{~N}_{2} \mathrm{O}-\mathrm{N} \mathrm{ha}^{-1} \mathrm{~d}^{-1}$ on the unfertilised control plot (CAN_0) to $48 \mathrm{~g} \mathrm{~N}_{2} \mathrm{O}-$ $\mathrm{N} \mathrm{ha}{ }^{-1} \mathrm{~d}^{-1}$ on the plot receiving the highest fertiliser application in combination with cattle slurry (CS_100) (Fig. 4). Generally, the highest $\mathrm{N}_{2} \mathrm{O}$ fluxes occurred in the first week after fertiliser or cattle 
slurry application. No differences in the general emission pattern could be observed between fertiliser and cattle slurry treatments.

On three occasions, fertiliser and manure application was not followed by a distinct peak emission. For the second application in 2001 and the fifth application in 2002, the absence of a peak coincided with a longer period of drought. In the case of the first application in 2002 there was no evidence of dry soil conditions and the absence of the peak remains unclear

Emission peaks did not exclusively occur directly after application. For instance, the increased fluxes occurring on the 8th of August 2002, just a week before the fourth application, coincided with $14 \mathrm{~mm}$ rainfall 1 day earlier and $37 \mathrm{~mm}$ rainfall 3 days earlier.

Emissions outside the growing season, measured between October 2001 and March 2002. were only
$4 \%$ of the annual emission (Table 1). Therefore, and for better comparability with the second year, we mainly present and analyse the accumulated emissions between March and October of each year.

On the control plots, the total $\mathrm{N}_{2} \mathrm{O}$ emissions were 0.04 and $0.13 \mathrm{~kg} \mathrm{~N} \mathrm{ha}^{-1}$ in the first and second year, respectively (Table 1). Application of fertiliser and cattle slurry increased the emissions up to levels of $1.41 \mathrm{~kg} \mathrm{~N} \mathrm{ha}^{-1}$ in 2001 and $1.14 \mathrm{~kg} \mathrm{~N} \mathrm{ha}^{-1}$ in 2002. In both years, $\mathrm{N}_{2} \mathrm{O}$ emissions increased with fertiliser levels $(P<0.001)$, irrespective of whether cattle slurry was applied or not. The average emissions were higher on the manured plots than on the fertiliser-only plots $(P<0.001)$.

\section{Emission factors}

For the fertiliser-only treatments, the average emission factors, calculated as the percentage of applied $\mathrm{N}$
Fig. 4 Nitrous oxide emissions during the experiment of four selected treatments. Vertical lines represent the application date of fertiliser and cattle slurry
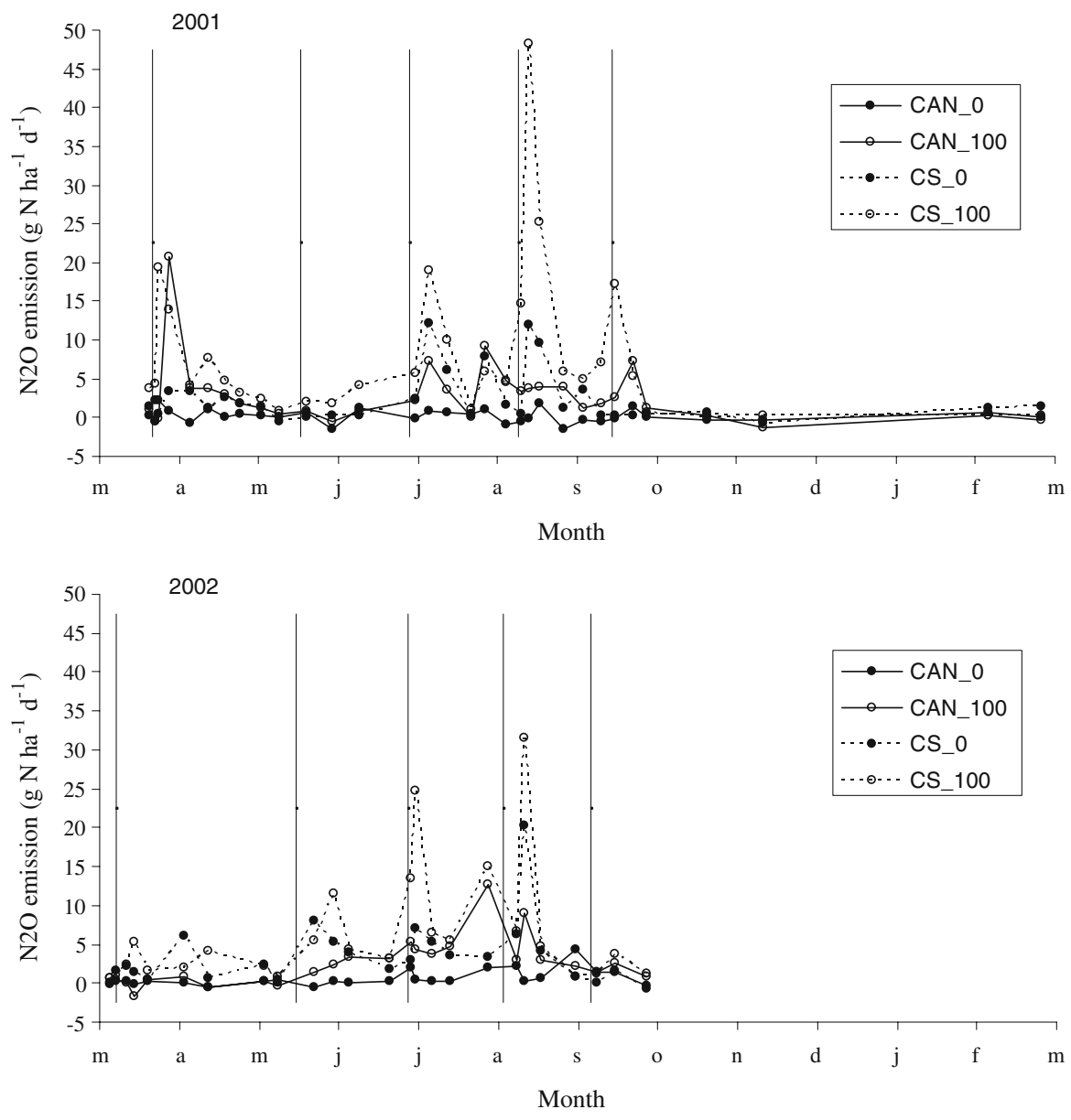
(EF_applied), were 0.17 and $0.13 \%$ in 2001 and $200 \overline{2}$, respectively (Table 1 ). The inclusion of the measurements outside the growing season, between October 2001 and March 2002, did not affect the emission factor for that year. The emission factor of the slurry-only (CS_0) treatment was 0.11 and $0.12 \%$ in 2001 and 2002, respectively. The effect of cattle slurry application on the emission factor of fertiliser was not consistent. In the first year, the average emission factor of fertiliser was $0.35 \%$ on the CS-treatments, compared to $0.17 \%$ on the CAN-treatments. Regression analysis confirmed the higher emission factor for fertiliser $(P<0.05)$ on the plots with cattle slurry application (Fig. 5). In the second year however, there was no effect of cattle slurry application on the emission factor for fertiliser. The average emission factor of fertiliser was $0.09 \%$ on the CS-treatments, compared to $0.13 \%$ on the CAN-treatments. Regres- sion analysis showed no effects of $\mathrm{N}$ source on the $\mathrm{N}_{2} \mathrm{O}$ emission in 2002.

The emission factor based on the $\mathrm{N}$ uptake of the grass crop (EF_uptake) varied from $0.07 \%$ on unfertilised plots (CAN_0) to $0.38 \%$ on plots receiving the highest combination of cattle slurry plus fertiliser (CS_100) (Table 1). In both years, the emission factors were significantly higher on treatments with cattle slurry application, viz. $0.29 \%$ compared to $0.17 \%$ for the fertiliser-only treatments. Regression analysis also showed the significantly higher $\mathrm{N}_{2} \mathrm{O}$ emission per $\mathrm{kg} \mathrm{N}$ uptake on the cattle slurry treatments (Fig. 5). In 2001, cattle slurry enhanced the emission of fertiliser $\mathrm{N}$, which is similar to the effect observed with the conventional emission factor.

For the fertiliser-only treatments, the average $\mathrm{N}$ surplus varied from -72 to $+55 \mathrm{~kg} \mathrm{~N} \mathrm{ha}^{-1}$ year $^{-1}$. The cattle slurry treatments had an average $\mathrm{N}$ surplus
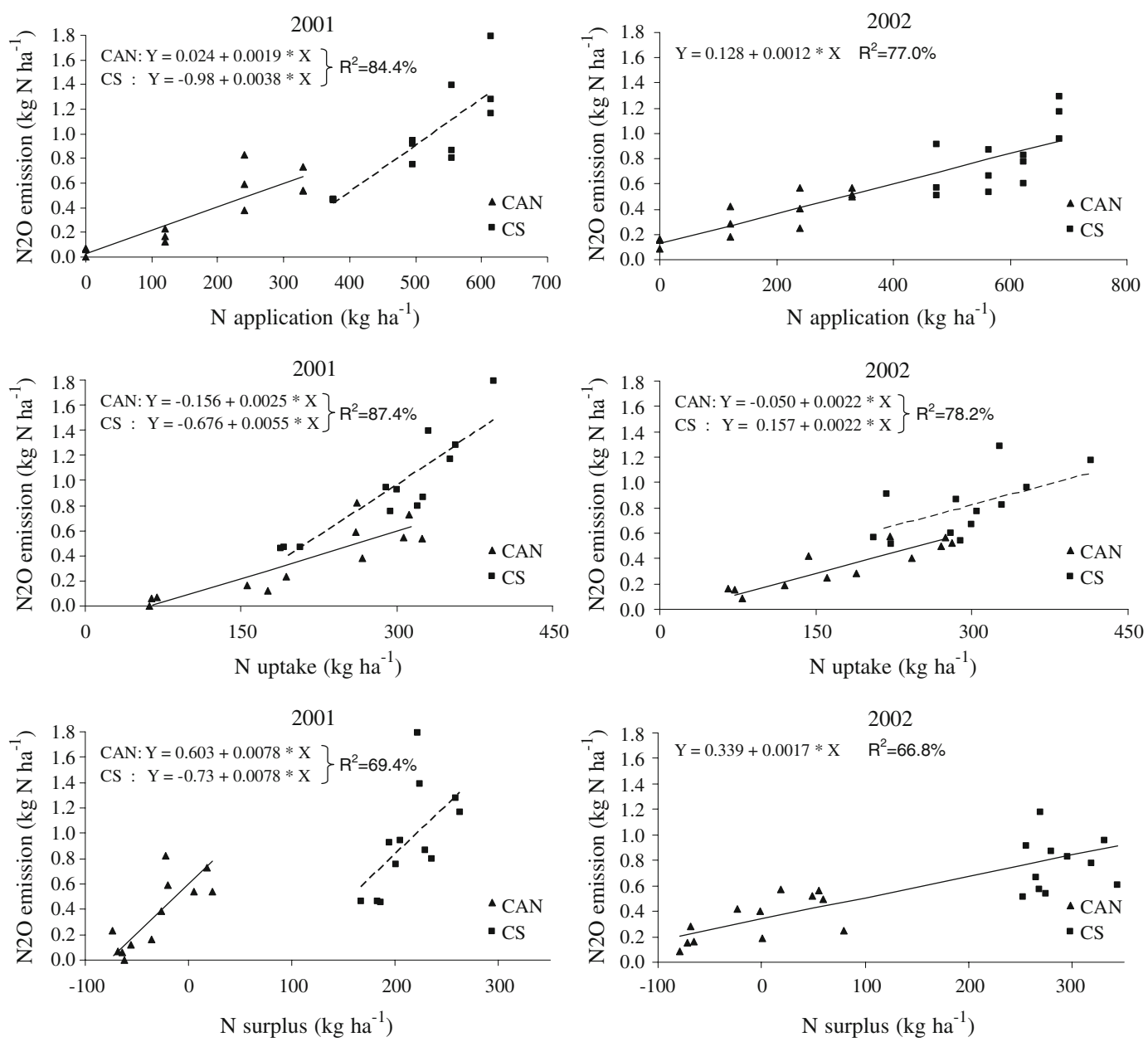

Fig. 5 Annual nitrous oxide emission in relation to applied $\mathrm{N}, \mathrm{N}$ uptake and $\mathrm{N}$ surplus 
between 179 to $319 \mathrm{~kg} \mathrm{~N}^{-1}$ year $^{-1}$. The emission factor, calculated as a percentage of the $\mathrm{N}$ surplus (EF_surplus) varied from -2.6 to $3.9 \%$ (Table 1 ). In 2001 , N level had an effect $(P<0.001)$ on the emission factor, but only within the fertilizer-only treatments.

\section{Discussion and conclusions}

Nitrogen efficiency

The average annual $\mathrm{N}$ uptake of the unfertilised control plots was $69 \mathrm{~kg} \mathrm{~N} \mathrm{ha}^{-1}$ year ${ }^{-1}$, which is in the low end of the range of 50 to $250 \mathrm{~kg} \mathrm{ha}^{-1}$ which is typical for Dutch grasslands (Vellinga and Andre 1999). The low annual $\mathrm{N}$ uptake on unfertilised plots indicates a low soil $\mathrm{N}$ supply (Hassink 1995). The average ANR of applied fertiliser $\mathrm{N}$ was $82 \%$ in the first year and $61 \%$ in the second year. The lower ANR in the second year corresponds with the higher accumulation of soil inorganic $\mathrm{N}$ in that year. It may be hypothesised that in the second year a larger part of fertiliser N, not taken up by the grass, accumulated in the soil profile.

The average ANR of cattle slurry $\mathrm{N}$ was $33 \%$, which is nearly half of the ANR of fertiliser. In terms of fertilising value, each $\mathrm{kg}$ of slurry $\mathrm{N}$ was equivalent to $0.46 \mathrm{~kg}$ of fertiliser $\mathrm{N}$, which is within the usual range for this application technique (Schils and Kok 2003). The lower ANR of cattle slurry is partly caused by ammonia losses, which are typically around 5 to $10 \%$ of total $\mathrm{N}$ for the shallow injection technique (Huijsmans et al. 2001). Furthermore approximately $50 \%$ of the slurry $\mathrm{N}$ is of organic origin with a low ANR in the year of application. However, this also implies an additional supply of nitrogen to the soil, mainly of organic origin. The observed accumulation of soil $\mathrm{NO}_{3}{ }^{-}-\mathrm{N}$ on cattle slurry treatments indicates a fast turnover of $\mathrm{NH}_{4}{ }^{+}-\mathrm{N}$ originating from cattle slurry. Furthermore, the lower ANR of cattle slurry is clearly reflected in the higher $\mathrm{N}$ surpluses for the slurry treatments.

$\mathrm{N}_{2} \mathrm{O}$ emission levels

The observed $\mathrm{N}_{2} \mathrm{O}$ emission levels in this experiment were rather low compared to the IPCC default emission factor of $1.00 \%$. The average emission factor for CAN fertiliser of $0.15 \%$ is in the lower end of the range, from 0.02 to $3.85 \%$, reported in an overview of 31 experiments in the Netherlands (Kuikman et al. 2006). In an experiment on grassland, Velthof and Oenema (1995b) determined emission factors of $0.5,1.4$ and $3.1 \%$ for sand, clay and peat soils, respectively. The increasing emissions from sand to peat are usually attributed to increasing moisture contents in combination with increasing organic matter contents. We suspect that the low values of WFPS during our experiment is the driving factor for the low $\mathrm{N}_{2} \mathrm{O}$ emissions, in line with findings in literature (Del Prado et al. 2006; van Groenigen et al. 2005), that suggest maximal $\mathrm{N}_{2} \mathrm{O}$ losses at 70 to $80 \%$ WFPS. The sparse WFPS measurements in our experiment are not conclusive, but the observed range between 18 and 55\% suggests poor conditions for $\mathrm{N}_{2} \mathrm{O}$ production.

The emissions showed a temporal variation that was mainly driven by fertiliser and cattle slurry application events. Emission peaks generally occurred within the first week following application of fertiliser and cattle slurry. This is in agreement with other studies on intensively managed grasslands (Velthof and Oenema 1995b). Grasslands can rapidly absorb the applied $\mathrm{N}$, and soil mineral $\mathrm{N}$ contents usually decrease rapidly within 2 weeks of application. Therefore the period of highest $\mathrm{N}_{2} \mathrm{O}$ emission risk on grasslands are found within the first 2 weeks after application. The measurement frequency was fixed beforehand with a focus on frequent measurements during the first 2 weeks after application.

\section{Effects of cattle slurry}

The two experimental years gave contrasting results with regard to the effect of cattle slurry on the $\mathrm{N}_{2} \mathrm{O}$ emission of fertiliser N. In the first year, the emission of fertiliser $\mathrm{N}$ was doubled in the presence of cattle slurry, but in the second year there was no significant effect. Reporting results from treatments with surface application of cattle slurry, Stevens and Laughlin (2001) found a threefold increase of the emission from $\mathrm{KNO}_{3}$ fertiliser. In a short-term experiment, Dittert et al. (2005) also observed significant increases in the emission from CAN fertiliser when applied in combination with cattle slurry. The set-up of the experiment does not allow an in-depth analysis of the underlying mechanisms of $\mathrm{N}_{2} \mathrm{O}$ production with or without cattle slurry application. 
It might be hypothesized however that the contact area between applied fertilizer and injected cattle slurry is less than with surface applied cattle slurry. Therefore the risk of increased $\mathrm{N}_{2} \mathrm{O}$ emissions from fertilizer might be lower with injection than with surface application.

If cattle slurry was applied alone, the emission factor was not different from fertiliser alone. By contrast, under very wet conditions, Velthof et al. (1996) measured a much higher emission from CAN fertiliser than from cattle slurry.

We hypothesized that the supply of easily degradable slurry $\mathrm{C}$ would increase the $\mathrm{N}_{2} \mathrm{O}$ losses from fertiliser derived $\mathrm{NO}_{3}$. The findings in the first year confirmed our hypothesis. It is unclear why the second year showed no effect of cattle slurry on $\mathrm{N}_{2} \mathrm{O}$ emissions from fertiliser. The second year showed a higher accumulation of soil inorganic N. Under those circumstances, the additional supply of slurry derived $\mathrm{C}$ will not increase $\mathrm{N}_{2} \mathrm{O}$ production. Furthermore, the differences in $\mathrm{N}_{2} \mathrm{O}$ emissions between both years may have been caused by differences in the ratio between $\mathrm{N}_{2} \mathrm{O}$ and $\mathrm{N}_{2}$ production during denitrification (Firestone et al. 1980; Granli and Bøckman 1994). The choice for a location on dry sandy soil might have contributed to the lack of a consistent interaction between fertiliser and cattle slurry. Nevertheless, the risk of increased emissions following simultaneous fertiliser and cattle slurry application remains, as demonstrated clearly by the results in the first year.

\section{Emission factors}

The three differently derived emission factors used in this paper allow alternative interpretations of the results. The emission per $\mathrm{kg} \mathrm{N}$ uptake (EF_uptake) was consistently higher on treatments with cattle slurry application, whereas the emission per $\mathrm{kg}$ applied N (EF_applied) provided no consistent effect of cattle slurry application. Similar results were also obtained in experiments on maize, where cattle slurry treatments emitted more $\mathrm{N}_{2} \mathrm{O}$ per $\mathrm{kg} \mathrm{N}$ uptake than fertiliser-only treatments (van Groenigen et al. 2004). Therefore, the emission factor based on $\mathrm{N}$ uptake expresses the relatively inefficient $\mathrm{N}$ supply of cattle slurry to crop growth better than the emission factors based on $\mathrm{N}$ application. Focussing on the $\mathrm{N}_{2} \mathrm{O}$ emissions in the plant soil component of agro- ecosystems, the use of fertiliser would be preferable over the use of cattle slurry. However, this would not be valid in a whole system analysis, especially in animal systems where cattle slurry is a primary component of the $\mathrm{N}$ cycle.

The $\mathrm{N}$ surplus of cropping and farming systems is an important environmental indicator for $\mathrm{N}$ losses to air and water (Schroder et al. 2003). As $\mathrm{N}_{2} \mathrm{O}$ emissions also occur with negative $\mathrm{N}$ surpluses, the emission per $\mathrm{kg} \mathrm{N}$ surplus (EF_surplus) can have a negative value, complicating the interpretation of this type of emission factor. Moreover, in our study the EF_surplus showed no consistent relationship with the imposed treatments. Therefore this experiment does not allow a final judgment on the usefulness of this emission factor.

\section{Conclusions}

The overall mean annual $\mathrm{N}_{2} \mathrm{O}$ emissions of all fertilised and manured treatments was $0.14 \%$ of applied $\mathrm{N}$, which is low compared to the IPCC default of $1.0 \%$. There was no consistent effect of cattle slurry application on the $\mathrm{N}_{2} \mathrm{O}$ emission of fertiliser. Cattle slurry application increased the fertiliser $\mathrm{N}_{2} \mathrm{O}$ emission in the first year, but had no effect in the second year. The location of the experiment on a relatively dry sandy soil has most likely contributed to the low emission levels and the lack of a consistent interaction between fertiliser and cattle slurry. With regard to the first objective, we conclude that these results don't conclusively justify an adjusted emission factor for combined application of fertiliser and cattle slurry. To minimise risks however, it is sensible to avoid simultaneous application of fertiliser and cattle slurry.

The $\mathrm{N}_{2} \mathrm{O}$ emission per $\mathrm{kg} \mathrm{N}$ uptake might have additional merit next to the emission per $\mathrm{kg} \mathrm{N}$ applied, as it better represent the crops effectiveness in biomass production. The use of cattle slurry consistently increased the $\mathrm{N}_{2} \mathrm{O}$ emission per $\mathrm{kg} \mathrm{N}$ uptake. Therefore with regard to the second objective we conclude that an emission factor based on $\mathrm{N}$ uptake expresses the relatively inefficient $\mathrm{N}$ supply of cattle slurry to crop growth better than the traditional emission factor based on $\mathrm{N}$ application.

Acknowledgements We thank Willy de Groot, Eduard Hummelink and Piotr Burczyk for the field measurements. 
Funding for this study was provided by the Dutch Ministery of Agriculture, Nature and Food Quality, the Reduction Programme Non- $\mathrm{CO}_{2}$ Greenhouse Gases and the Programme Climate changes Spatial Planning (Project ME1).

Open Access This article is distributed under the terms of the Creative Commons Attribution Noncommercial License which permits any noncommercial use, distribution, and reproduction in any medium, provided the original author(s) and source are credited.

\section{References}

Bouwman AF (1996) Direct emission of nitrous oxide from agricultural soils. Nutr Cycl Agroecosyst 46:53-70. DOI 10.1007/BF00210224

Bouwman AF, Boumans LJM, Batjes NH (2002) Emissions of $\mathrm{N} 2 \mathrm{O}$ and $\mathrm{NO}$ from fertilized fields: summary of available measurement data. Glob Biogeochem Cycles 16(4), 1058, DOI 10.1029/2001GB001811

Christensen S (1983) Nitrous-oxide emission from a soil under permanent grass - seasonal and diurnal fluctuations as influenced by manuring and fertilization. Soil Biol Biochem 15:531-536. DOI 10.1016/0038-0717(83)90046-9

Clayton H, McTaggart IP, Parker J, Swan L, Smith KA (1997) Nitrous oxide emissions from fertilised grassland: a 2-year study of the effects of $\mathrm{N}$ fertiliser form and environmental conditions. Biol Fertil Soils 25:252-260. DOI 10.1007/ s003740050311

Del Prado A, Merino P, Estavillo JM, Pinto M, GonzalezMurua C (2006) N2O and NO emissions from different N sources and under a range of soil water contents. Nutr Cycl Agroecosyst 74:229-243. DOI 10.1007/s10705-0069001-6

Dittert K, Lampe C, Gasche R, Butterbach-Bahl K, Wachendorf M, Papen H, Sattelmacher B, Taube F (2005) Short-term effects of single or combined application of mineral $\mathrm{N}$ fertilizer and cattle slurry on the fluxes of radiatively active trace gases from grassland soil. Soil Biol Biochem 37:1665-1674. DOI 10.1016/j.soilbio.2005.01.029

EEA (2006) Annual European Community greenhouse gas inventory 1990-2004 and inventory report 2006. European Environment Agency, Copenhagen

FAO (1998) World reference base for soil resources. Food and Agriculture Organization of the United Nations, Rome

Firestone MK, Firestone RB, Tiedje JM (1980) Nitrous-oxide from soil denitrification - factors controlling its biological production. Science 208:749-751. Medline DOI 10.1126/ science.208.4445.749

GENSTAT (2007) GENSTAT Release 9.2. Lawes Agricultural Trust (Rothamsted Experimental Station)

Granli T, Bøckman OC (1994) Nitrous oxide from agriculture. Nor J Agric Sci (suppl. 12):1-128

Hassink J (1995) Prediction of the non-fertilizer n-supply of mineral grassland soils. Plant Soil 176:71-79. DOI 10.1007/BF00017677

Huijsmans JFM, Hol JMG, Hendriks MMWB (2001) Effect of application technique, manure characteristics, weather and field conditions on ammonia volatilization from manure applied to grassland. Neth J Agric Sci 49:323-342

IPCC (2006) Guidelines for National Greenhouse Gas Inventories, prepared by the National Greenhouse Gas Inventories Programme. Intergovernmental Panel on Climate Change

Kuikman PJ, van der Hoek KW, Smit A, Zwart K (2006) Update of emission factors for nitrous oxide from agricultural soils on the basis of measurements in the Netherlands. In Alterra-rapport;1217. Alterra, Wageningen

Li C, Frolking S, Frolking TA (1992) A model of nitrous oxide evolution from soil driven by rainfall events: 1. Model structure and sensitivity. J Geophys Res 97:9759-9776

Mosier AR, Duxbury JM, Freney JR, Heinemeyer O, Minami K (1998) Assessing and mitigating N2O emissions from agricultural soils. Clim Change 40:7-38. DOI 10.1023/ A:1005386614431

Rodhe L, Pell M, Yamulki S (2006) Nitrous oxide, methane and ammonia emissions following slurry spreading on grassland. Soil Use Manage 22:229-237. DOI 10.1111/j.14752743.2006.00043.x

Ryden JC (1983) Denitrification loss from a grassland soil in the field receiving different rates of nitrogen as ammonium-nitrate. J Soil Sci 34:355-365

Schils RLM, Kok I (2003) Effects of cattle slurry manure management on grass yield. Neth J Agric Sci 51:41-65

Schroder JJ, Aarts HFM, Ten Berge HFM, van Keulen H, Neeteson JJ (2003) An evaluation of whole-farm nitrogen balances and related indices for efficient nitrogen use. Eur J Agron 20:33-44. DOI 10.1016/S1161-0301(03)00070-4

Schröder JJ, Aarts HFM, Van Middelkoop JC, Schils RLM, Velthof GL, Fraters B, Willems WJ (2007) Permissible manure and fertilizer use in dairy farming systems on sandy soils in The Netherlands to comply with the nitrates directive target. Eur J Agron 27:102-114. DOI 10.1016/j. eja.2007.02.008

Stehfest E, Bouwman L (2006) N2O and NO emission from agricultural fields and soils under natural vegetation: summarizing available measurement data and modeling of global annual emissions. Nutr Cycl Agroecosyst 74:207-228. DOI 10.1007/s10705-006-9000-7

Stevens RJ, Laughlin RJ (2001) Cattle slurry affects nitrous oxide and dinitrogen emissions from fertilizer nitrate. Soil Sci Soc Am J 65:1307-1314

Stevens RJ, Laughlin RJ (2002) Cattle slurry applied before fertilizer nitrate lowers nitrous oxide and dinitrogen emissions. Soil Sci Soc Am J 66:647-652

Unwin RJ, Vellinga TV (1994) Fertiliser recommendations for intensively managed grassland. In: 't Mannetje L, Frame J (eds) Grassland and society. Proceedings of the 15th general meeting of the European grassland federation. Wageningen, Wageningen, pp 590-602

van Groenigen JW, Kasper GJ, Velthof GL, Van den Pol-van Dasselaar A, Kuikman PJ (2004) Nitrous oxide emissions from silage maize fields under different mineral nitrogen fertilizer and slurry applications. Plant Soil 263: 101-111

Van Groenigen JW, Velthof GL, van der Bolt FJE, Vos A, Kuikman PJ (2005) Seasonal variation in N2O emissions from urine patches: effects of urine concentration, soil 
compaction and dung. Plant Soil 273:15-27. DOI 10.1007/s11104-004-6261-2

Vellinga TV, Andre G (1999) Sixty years of Dutch nitrogen fertiliser experiments, an overview of the effects of soil type, fertiliser input, management and of developments in time. Neth J Agric Sci 47:215-241

Velthof GL, Oenema O (1995a) Nitrous oxide fluxes from grassland in the Netherlands. 1. Statistical analysis of fluxchamber measurements. Eur J Soil Sci 46:533-540. DOI 10.1111/j.1365-2389.1995.tb01349.x

Velthof GL, Oenema O (1995b) Nitrous oxide fluxes from grassland in the Netherlands. 2. Effects of soil type, nitrogen fertilizer application and grazing. Eur J Soil Sci 46:541-549. DOI 10.1111/j.1365-2389.1995.tb01350.x

Velthof GL, Oenema O, Postma R, VanBeusichem ML (1996) Effects of type and amount of applied nitrogen fertilizer on nitrous oxide fluxes from intensively managed grassland. Nutr Cycl Agroecosyst 46:257-267

Velthof G, Oudendag DA, Oenema O (2007) Development and application of the integrated nitrogen model MITERRAEUROPE. Alterra, Wageningen

Williams DL, Ineson P, Coward PA (1999) Temporal variations in nitrous oxide fluxes from urine-affected grassland. Soil Biol Biochem 31:779-788. DOI 10.1016/S0038-0717(98)00186-2 